\title{
Submerged Rootless Macrophytes Sustain a Stable State Against Free- Floating Plants
}

\author{
Sándor Szabó, ${ }^{1}$ Gergő Koleszár, ${ }^{2}$ Mihály Braun, ${ }^{3}$ Zoltán Nagy, ${ }^{4}$ \\ Tibor T. Vicei, ${ }^{1}$ and Edwin T. H. M. Peeters ${ }^{5 *}{ }_{\odot}$
}

\begin{abstract}
${ }^{1}$ Department of Biology, University of Nyiregyhaza, Nyiregyhaza 4401, PF: 166, Hungary; ${ }^{2}$ Department of Tisza Research, Centre for Ecological Research, Eötvös Loránd Research Network, Bem square 18/C, Debrecen 4026, Hungary; ${ }^{3}$ Isotope Climatology and Environmental Research Centre (ICER), Institute for Nuclear Research, Eötvös Loránd Research Network, Bem tér 18/C, Debrecen 4026, Hungary; ${ }^{4}$ Tuzson János Botanical Garden, University of Nyiregyhaza, Nyiregyhaza 4401, PF: 166, Hungary; ${ }^{5}$ Aquatic Ecology and

Water Quality Management Group, Wageningen University and Research, PO Box 8080, 6700 Wageningen, The Netherlands
\end{abstract}

\begin{abstract}
Both non-rooted submerged vegetation dominated by coontail (Ceratophyllum demersum) and non-rooted floating duckweed vegetation (Lemna gibba) can maintain their stable dominance in small ponds and channels. We examined the competitive interactions between them and how Ceratophyllum can sustain its stable state against floating plants in a range of nutrient concentrations. Coontail and duckweed were co-cultured in static and semi-static microcosm experiments, and their impact on the nutrients $(\mathrm{N}, \mathrm{P}, \mathrm{Fe}, \mathrm{Mn})$ in the water column was analysed. Coontail strongly reduced the growth of duckweed under a low nitrogen level (0.2$2 \mathrm{mg} \mathrm{N} \mathrm{L}^{-1}$ ). This reduction seems to be due to the low availability of nutrients in the water as derived from the lower nutrient concentrations in duckweed tissue or high $\mathrm{pH}$ in water. High nitrogen levels in semi-static media $\left(5-10 \mathrm{mg} \mathrm{N} \mathrm{L}^{-1}\right)$ resulted in an
\end{abstract}

Received 12 October 2020; accepted 15 March 2021; published online 4 May 2021

Supplementary Information: The online version contains supplementary material available at https://doi.org/10.1007/s10021-021-0063 7-5.

Author contributions: SS and EP conceived the idea; SS, GK, MB, ZN, TV, EP performed study; SS, GK, EP analysed data; SS, GK, EP wrote manuscript.

*Corresponding author; e-mail: edwin.peeters@wur.nl increasingly higher chance to overgrow $C$. demersum by $L$. gibba. Field observations revealed that $C$. demersum dominated over $L$. gibba in water bodies with total $\mathrm{N}$ below $3 \mathrm{mg} \mathrm{L}^{-1}$, while L. gibba dominance over $C$. demersum occurred above $5 \mathrm{mg} \mathrm{L}^{-1}$ total N. Ceratophyllum occurrence correlated negatively with total $\mathrm{N}$ in the water, while Lemna showed a positive correlation. Furthermore, the occurrence of $L$. gibba was negatively correlated with the frequency of $C$. demersum. All findings together support the theory that under a certain nutrient range, rootless submerged macrophytes have a strong potential to inhibit the dominance of floating plants in ponds, ditches and channels, and thus, they stabilize the submerged vegetation state.

Key words: ceratophyllum; competition; floating plants; nutrient limitation; lemna; stable state; submerged macrophytes.

\section{HighLights}

- Coontail strongly reduced duckweed growth under low nitrogen level in an experiment 
- Field data showed coontail dominance over duckweed in waters with $<3 \mathrm{mg}$ total $\mathrm{N} \mathrm{L}^{-1}$

- Rootless submerged macrophytes potentially inhibit the dominance by floating plants

\section{INTRODUCTION}

Alternative stable states in freshwater ecosystems are well known from shallow lakes that could be either in a state of crystal-clear water dominated by rooted, submerged macrophytes or in the turbid state dominated by phytoplankton (Scheffer and others 1993). Internal, positive feedbacks like the capacity of the vegetation to clean-up the water, tend to keep the state in its present state. In more sheltered water systems, non-rooted floating plants may thrive very well and take over the role of phytoplankton leading to a state dominated by either mats of non-rooted floating plants or rooted, submerged plants (Scheffer and others 1993). Availability of light and nutrients play a crucial role in the alternative states (Scheffer and others 1993).

Availability of nutrients and light are also two essential factors regulating the growth and distribution of aquatic primary producers (Chambers 1987; Chambers and Kalf 1987; Bornette and Puijalon 2011). Eutrophication may drastically change nutrient conditions and that might be detrimental for certain species, while others may benefit from it (Cao and others 2011; Phillips and others 2016). Ponds and ditches are usually less exposed to wind and higher nutrient concentrations in these, windsheltered, places make them susceptible to the dominance of free-floating macrophytes (Morris and others 2003; Peeters and others 2013; Smith 2014). On the other hand, the lower water depth may favour growth of submerged macrophytes resulting in ditches totally covered by these macrophytes (van Zuidam and Peeters 2013; Smith 2014). The competitive advantage of submerged macrophytes depends on their capacity to take up nutrients from the sediment as well as from the water column, thereby lowering the available nutrients in the water column for floating plants (Szabo and others 2010). The presence of freefloating vegetation has a strong influence on the light available for the submerged plants (Larson 2007; Lu and others 2013) as have planktonic and periphytic algae (Brönmark and Vermaat 1998; Tóth 2013; Phillips and others 2016), and by shading of neighbouring plants (Szabó and others 2020). Because floating plants are on top, their shading will strongly hamper the survival and growth of submerged plants (Scheffer and others
2003), but canopy-forming submerged species such as Ceratophyllum demersum have a chance to persist. This asymmetric competition for light and nutrients results in the dominance of submerged macrophytes under lower nutrient levels and the dominance of floating plants under more eutrophic conditions (Smith 2014; van Gerven and others 2015).

Empirical studies that have addressed the interactions between these two groups of macrophytes principally focused on the impact of floating plants on submerged plants (Morris and others 2004; Larson 2007; Lu and others 2013), and little has been done on the effect of submerged vegetation on floaters. Field observation indicated that an abundance of floating plants above dense stands of submerged rooted vegetation was low (Scheffer and others 2003; van Zuidam and Peeters 2013), suggesting a limiting effect of submerged plants on floaters. Laboratory experiments also demonstrated that submerged rooted vegetation was able to strongly limit the growth of free-floating plants (Szabo and others 2010).

Coontail (Ceratophyllum demersum), a non-rooted submerged species, plays an important role in the functioning of aquatic ecosystems especially when it dominates the community. They often form dense stands in shallow lakes, ponds, and ditches worldwide, especially under elevated nutrient levels (Lombardo and Cooke 2003). It is also known that coontail may play a key role in sustaining the clear water state (with low turbidity) since Ceratophyllum dominance was associated with low phytoplankton abundance even at elevated phosphate concentrations (Mjelde and Faafeng 1997; Dai and others 2014). Interestingly, various observations showed the co-occurrence of the rootless submerged plant $C$. demersum with the floating plant $L$. gibba (Simons 1994; Feuchtmayr and others 2009; van Zuidam and Peeters 2013) and this raises the question concerning the competitive interactions between these two species.

Although Ceratophyllum is not rooted in the sediment, it probably has better access to nutrients because its position is closer to the sediment that releases nutrients and it has a larger nutrient absorbing surface than $L$. gibba. These characteristics offer Ceratophyllum a competitive advantage over $L$. gibba. Therefore, due to its relatively fast nutrient uptake, coontail may have the capacity to reduce the nutrient concentrations in the upper water body. Based on a field survey (van Zuidam and Peeters 2013), we hypothesize that non-rooted submerged vegetation may maintain their stable dominance against floating plants over a 
certain range of nutrient concentration due to their capacity to limit duckweed growth via nutrient reduction. The present study aims to evaluate this hypothesis by investigating how $C$. demersum alters nutrient conditions in the water column and how this affects the growth of floating plants (L. gibba). Growth experiments were performed in static and semi-static media mimicking different levels of nutrient limitation. Furthermore, monitoring data on the occurrence and abundance of $C$. demersum and L. gibba in Hungary and the Netherlands were studied in relation to nutrient concentrations.

\section{Material And Methods}

We collected fronds of $L$. gibba and shoots of $C$. demersum from the Igrice channel (N 47.996376 ${ }^{\circ}, \mathrm{E}$ $\left.21.734152^{\circ}\right)$, NE Hungary. We preincubated the plants for four months in 10-L plastic boxes containing a culture medium modified from Barko and Smart (1985). Nitrogen and phosphorus were supplied by adding a stock solution of $\mathrm{NH}_{4} \mathrm{NO}_{3}$ and $\mathrm{K}_{2} \mathrm{HPO}_{4}$ to a final, relatively high concentration of $5 \mathrm{mg} \mathrm{N} \mathrm{L}^{-1}$ and $1 \mathrm{mg} \mathrm{P} \mathrm{l}^{-1}$, respectively, to avoid rapid depletion due to plant growth. The chosen $\mathrm{N}$ and $\mathrm{P}$ concentrations were sufficient for the optimal cultivation of both species. We added TROPICA supplier micronutrient solution to ensure micronutrient supply using 5000-fold dilution reaching final concentrations in the medium of $\mathrm{Fe}$ 0.16 , Mn 0.90, Zn 0.004, $\mathrm{Cu} 0.012$ and Mo $0.004 \mathrm{mg} \mathrm{L}^{-1}$, respectively.

\section{Semi-static Experiment}

To study the development over a longer time period, an experiment with a semi-static medium was applied to mimic a situation where nutrient replenishment or release from the sediment to the water takes place. We removed water from the surface of the plants by using a salad centrifuge and then placed shoots of Ceratophyllum $(10-25 \mathrm{~cm}$ length) in 2-L plastic aquaria (height $11.5 \mathrm{~cm}$, width $11.5 \mathrm{~cm}$, length $18 \mathrm{~cm}$ ) without any sediment. The sides of the aquaria were covered with black foil to avoid light penetration from the sides. Initial biomass was as follows: $0 \mathrm{~g}$ (control), $5 \mathrm{~g}$, $20 \mathrm{~g}$ fresh weight $(\mathrm{FW})\left(0,250,1000 \mathrm{~g} \mathrm{~m}^{-2}\right)$. We co-cultured the plants with $500 \pm 2 \mathrm{mg}$ FW of Lemna $\left(25 \mathrm{~g} \mathrm{~m}^{-2}\right)$. We applied five treatments representing five different nitrogen concentrations by adding $\mathrm{NH}_{4} \mathrm{NO}_{3}$ to $0.2,1,2,5$ or $10 \mathrm{mg} \mathrm{N} \mathrm{L}^{-1}$. The initial concentration of phosphorus was the same as in the preincubation. The dilution of microelements was 10,000 . Three aquaria per treatment (in total 45 aquaria) were incubated for 50 days under the following conditions: $220 \mu \mathrm{mol} \mathrm{m}{ }^{-2} \mathrm{~s}^{-1}$ photon flux density, 16-h light/ 8-h dark. All aquaria were set into a temperaturecontrolled $\left(23-25^{\circ} \mathrm{C}\right)$ water bath. We renewed half of the medium $(1 \mathrm{~L})$ twice a week. The medium was drained by gravity, and fresh medium was gently added into the aquaria through a PVC tube placed at the corner. We measured FW of Lemna and Ceratophyllum on days 14 and 50 to calculate their relative growth rates (RGRs) as $\mathrm{RGR}=$ $\left(\operatorname{lnFW}_{t}-\operatorname{lnFW}_{0}\right) / t$ in which $\mathrm{FW}_{t}$ and $\mathrm{FW}_{0}$ were the fresh weights at time $t$ and time 0 , respectively. On day 33 (6 AM and 4 PM), we analysed water for $\mathrm{pH}$ and dissolved oxygen. On the 50th day, we harvested the plants and dried them at $80{ }^{\circ} \mathrm{C}$ for 2 days and then measured their dry weight.

\section{Static Experiment}

To take into account the depletion of nutrients, a static medium experiment was performed. We used 2-L black plastic aquaria containing culture media and placed L. gibba fronds in a PVC tube with a length of $9 \mathrm{~cm}$ and a diameter ranging from 2 to $10 \mathrm{~cm}$. The tube was placed vertically in each of the aquaria with the top just above the water surface, serving as a duckweed enclosure. Each tube had four holes on the side allowing nutrient transfer between the inner and outer water mass. We set portions of preincubated Lemna fronds (200 $\pm 2 \mathrm{mg}$ FW) inside the smallest enclosures and then placed shoots of Ceratophyllum in the aquaria outside the Lemna enclosures with the following densities: $0 \mathrm{~g}$ (control), $5 \mathrm{~g}, 20 \mathrm{~g}$ and $40 \mathrm{~g}$ FW $\left(0,250,1000,2000 \mathrm{~g} \mathrm{~m}^{-2}\right)$. As soon as Lemna fronds reached a $100 \%$ cover, we replaced the enclosure with a bigger one in diameter. This method allowed to cultivate free-floating plants on a static medium under optimal conditions avoiding algal inhibition and overcrowding (Szabó and others 2003, 2010). This set-up thus minimized the negative effects of shading by Lemna on the growth of Ceratophyllum, while effects of high $\mathrm{pH}$ due to submerged plants and uptake of nutrients by these submerged plants on Lemna can be examined.

We cultivated the macrophytes at five different nitrogen treatments $\left(0.5,1,2,5\right.$ and $\left.10 \mathrm{mg} \mathrm{N} \mathrm{L}^{-1}\right)$. The initial concentration of phosphorus and microelements was the same as in the preincubation. We used three aquaria per treatment meaning that 60 aquaria were used.

We incubated the cultures for 12 days under $220 \mu \mathrm{mol} \mathrm{m}{ }^{-2} \mathrm{~s}^{-1}$ photon flux density and 16-h light/8-h dark regime and measured the FW of 
Lemna fronds on days 4, 8 and 12. FW was used to calculate their relative growth rate at day $8\left(\mathrm{RGR}_{8}\right)$ and $12\left(\mathrm{RGR}_{12}\right)$. On the 12 th day, we harvested the plants. We used a portion of $100 \mathrm{mg}$ FW Lemna for chlorophyll determination. We extracted chlorophyll in $95 \%$ ethanol and determined the total chlorophyll content by spectrophotometry, according to Lichtentaler (1987). The main portion of Lemna was used for dry weight determination, to calculate chlorophyll concentration on a dry weight basis.

We took 20-20 ml water samples from all treatments at the initial, 2nd, 4th, 6th, 8 th and 12 th day. The volumes of the triplicates were merged and thereafter measured for $\mathrm{pH}$, then filtered and analysed for $\mathrm{PO}_{4}{ }^{3-}-\mathrm{P}, \mathrm{NO}_{3}{ }^{-}-\mathrm{N}, \mathrm{NH}_{4}{ }^{+}-\mathrm{N}$ (Technicon Auto Analyser, Skalar, Breda, the Netherlands), and Fe and Mn by ICP MS as described by Szabó and others (1999). At the end of the experiment, we analysed the total carbon and nitrogen concentration of the plants by dry combustion using a Vario Max Cube elemental analyzer (Elementar GMBH, Germany). Manganese content of Lemna was measured by ICP OES after acidic digestion using $5 \mathrm{~mL}$ of $67 \%(\mathrm{~m} / \mathrm{m})$ nitric acid and $5 \mathrm{~mL} \mathrm{30 \%} \mathrm{(m/m)} \mathrm{hydrogen} \mathrm{peroxide}$ at $90{ }^{\circ} \mathrm{C}$ for one hour.

\section{Analysis of Data from Field Surveys}

Using the Database of Hungarian Surface Waters, we collected data from water bodies (305 locations) where C. demersum $(n=274)$ and L. gibba $(n=66)$ occurred between July and September in the period 2005-2019. We correlated the total-N concentration of the water with the frequency of Ceratophyllum and Lemna as well. An abundance of the plants was expressed on DAFOR scale (Redhead and others 2014) that records the vegetative cover of an area and represents the abundance of the species: dominant $51-100 \%$ (5), abundant $31-50 \%$ (4), frequent $16-30 \%$ (3), occasional $6-15 \%$ (2), rare $1-5 \%(1)$.

We also used data from an inventory in the Netherlands, in detail described by van Zuidam and Peeters (2013). Information from 67 locations of Dutch ditches was gathered on the abundance of aquatic macrophytes (number of data C. demersum $\mathrm{n}=49 ; L$. gibba $\mathrm{n}=47$ ) and nutrient concentrations in the water in June and September 2007. Vegetation recordings were done according to the Tansley coverage classes (Tansley 1946) by selecting a representative, 25-m-long spot of the ditch. Plants were identified up to species level. Also, water samples were taken from the upper $20 \mathrm{~cm}$ of the water column and analysed for total nitrogen using a continuous flow analyser (Skalar Analytic BV, Breda, the Netherlands). Total nitrogen was determined after a UV/persulfate acidic destruction following standard protocols (NNI 1990,1997).

\section{Statistical Analyses}

For the laboratory experiments, we used the Kolmogorov-Smirnov test for checking the normality of the variables. Both in semi-static and static conditions the measured variables (RGR, chlorophyll concentration in the fronds) were normally distributed $(P>0.05)$. A general linear model (GLM) was used to test the significance of the factors (Ceratophyllum density, nitrogen concentration) and their interaction with the variables. We checked residuals for normality, and we evaluated the homogeneity of variances by Levene's test. We applied Tukey post hoc tests to evaluate which treatments differed from each other. We used pairwise comparisons (PC) to test the variables for significant differences among Ceratophyllum treatments, where the mean difference $(\mathrm{MD}) \pm$ standard error was indicated.

To analyse whether there was a significant relationship between the total-N concentration of the water and frequency (DAFOR classes) of both species, generalized linear models were applied with a multinomial distribution and a cumulative logit link. The DAFOR classes were the dependent variable, and nitrogen concentration was tested for significance. Tests were done for all data, but since the absence of a species can be caused by many different variables, the tests were also performed with observation where the species was present. All analyses were done in SPSS 25.0 software.

\section{Results}

Both experiments showed that biomass of Lemna increased with increasing $\mathrm{N}$ concentration and decreased with increasing Ceratophyllum densities. Ceratophyllum on the other hand decreased with increasing $\mathrm{N}$ concentration which was associated with higher Lemna biomass but only in the semistatic experiment. The laboratory experiments also showed that nitrogen concentration in the medium, Ceratophyllum density, and their interaction significantly $(P 0.006-<0.001$; ANOVA) influenced the Lemna RGR, chlorophyll concentration and dry matter content (DMC) both in the semistatic and the static experiment (Figures 1, 2, S1, S2, Table S1). Dry matter content (DW:FW ratio) of both species decreased with increasing $\mathrm{N}$ concentration. DMC of Lemna was positively influenced by Ceratophyllum treatment (Figure S3). DMC of Ceratophyllum was higher at lower plant densities. 

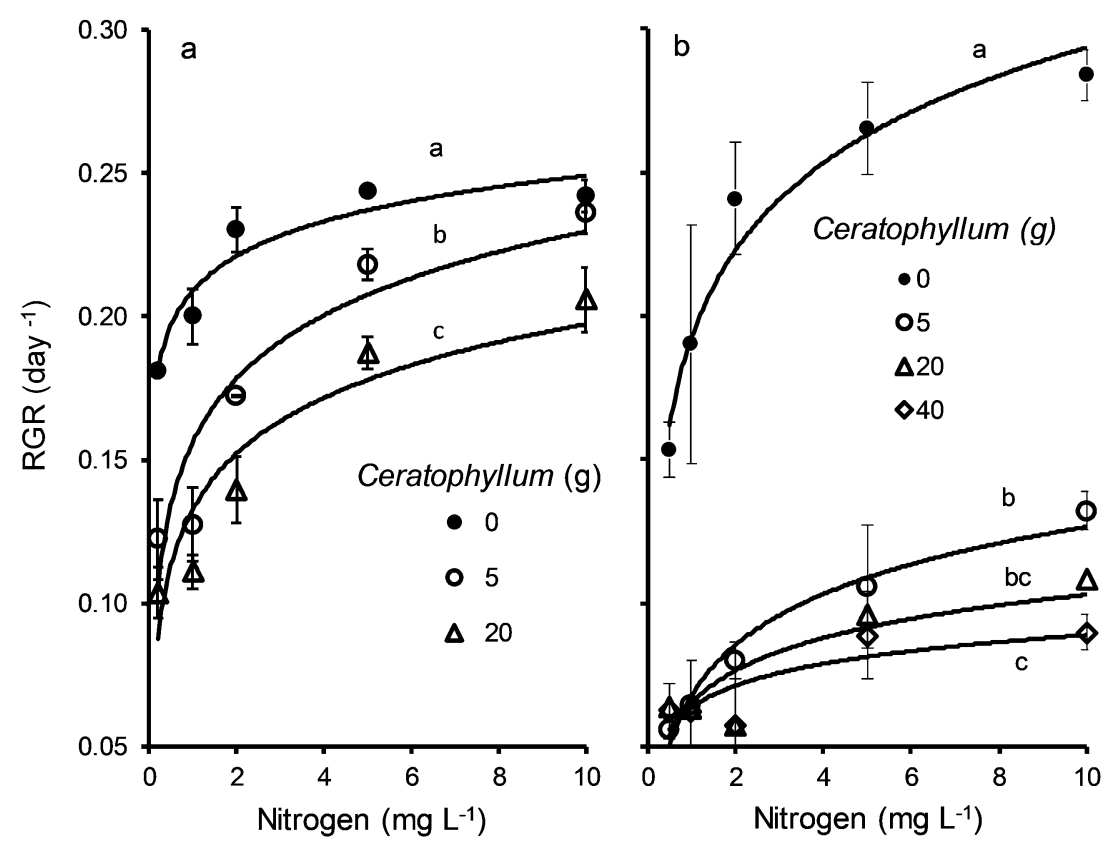

Figure 1. The impact of Ceratophyllum demersum on the relative growth rate (RGR) of Lemna gibba grown in semi-static medium at day 14 (mean $\pm \mathrm{SD}, n=3$ ) (A) and in static medium between day $0-8$ (mean \pm SD, $n=3)(\mathbf{B})$. Significant differences (Tukey's test, $P<0.05$ ) among Ceratophyllum treatments are per medium indicated with different lowercase letters.

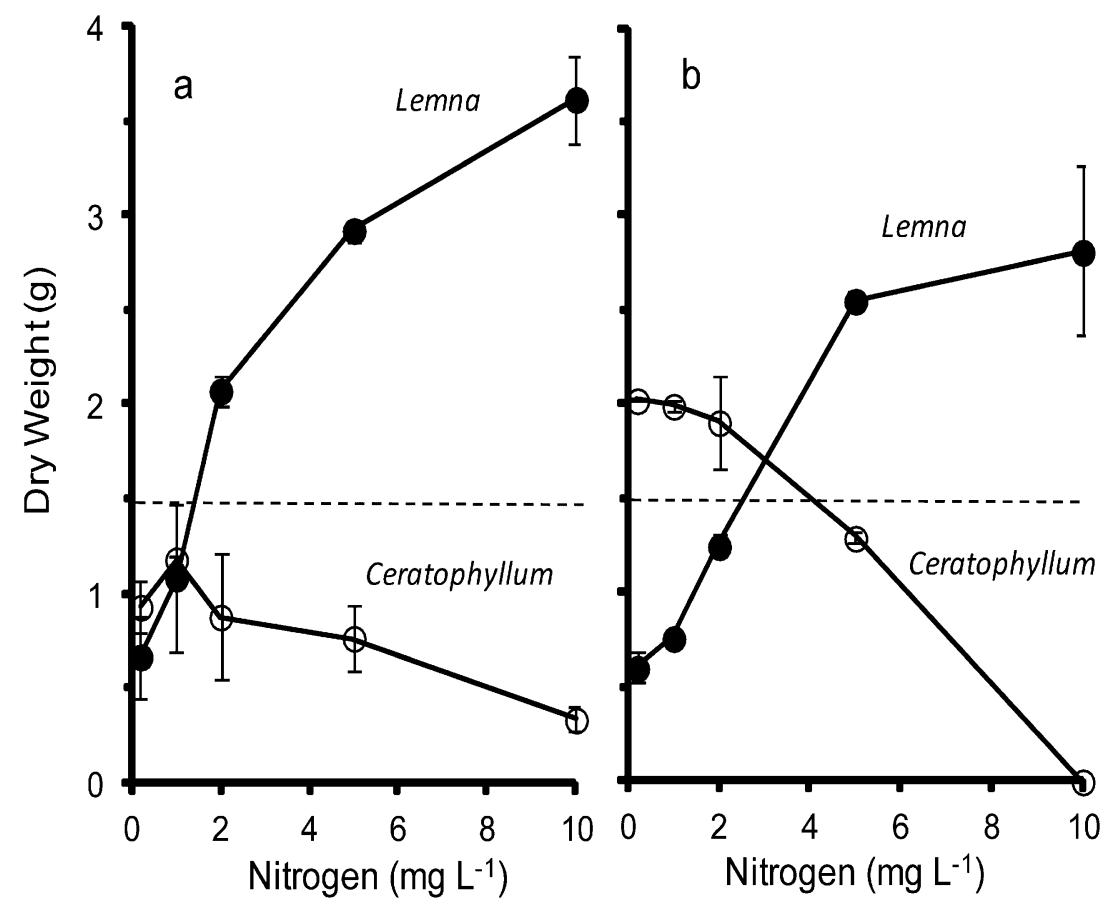

Figure 2. Dry weight of the plants in Lemna-Ceratophyllum co-cultures grown on semi-static media with different nitrogen concentrations after 50 days (mean SD, $n=3$ ) Initial biomass ratios for Lemna:Ceratophyllum were A 0.5:5 and B 0.5:20. 
DMC of Lemna negatively correlated with RGR and chl concentration of the plants.

\section{Semi-static Experiment}

In all treatments, Ceratophyllum showed growth in biomass except for the highest plant density $(20 \mathrm{~g})$ at $10 \mathrm{mg} \mathrm{N} \mathrm{L}^{-1}$ where Lemna fully covered the surface. RGR of Lemna increased with increasing $\mathrm{N}$ but levelled off at higher concentrations. A higher abundance of Ceratophyllum resulted in a stronger reduction of the growth of Lemna which was maximally $45 \%$ after 14 days (Figure 1A). A higher density of Ceratophyllum ( $20 \mathrm{~g})$ resulted in a significantly $(P<0.0001$, MD $0.026 \pm 0.003$, PC $)$ stronger reduction in Lemna growth than lower $(5 \mathrm{~g})$ density. For nitrogen concentration above $5 \mathrm{mg} \mathrm{N} \mathrm{L}^{-1}$, the reduction in Lemna growth due to the abundance of Ceratophyllum weakened by roughly 15\% (Figure 1A). Nitrogen concentration of the media had a significant $(P<0.001$, ANOVA) impact on the biomass of both Lemna and Ceratophyllum (Figure 2). In the presence of Ceratophyllum (40 g FW), Lemna covered the surface completely
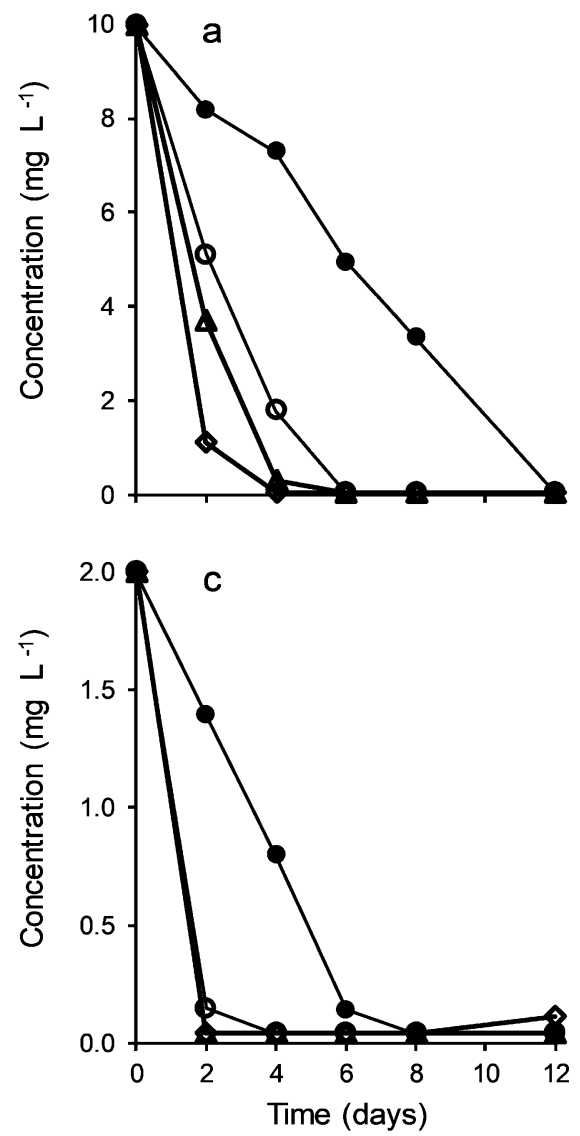

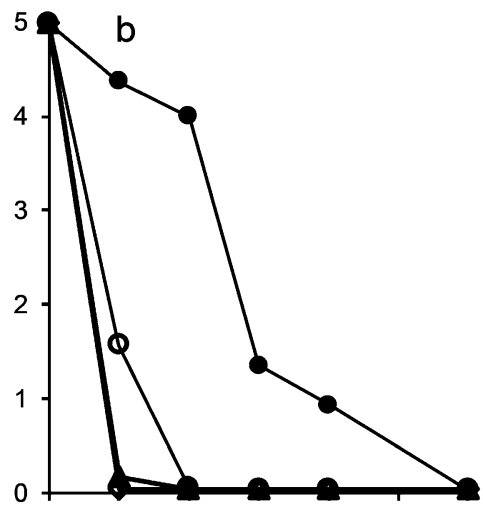

within 14 days at $10 \mathrm{mg} \mathrm{L}^{-1}$ and within 20 days at $5 \mathrm{mg} \mathrm{L}^{-1} \mathrm{~N}$ concentration, respectively. Despite the low initial biomass ratio (Lemna $0.5 \mathrm{~g}$ : Ceratophyllum $5 \mathrm{~g}$ ), Lemna overgrew the biomass of Ceratophyllum after 50 days, by $991 \%$ in the treatment with $10 \mathrm{mg} \mathrm{N} \mathrm{L}^{-1}$ (Figure 2A). The biomass of Ceratophyllum in co-cultures showed a gradual decline with increasing nitrogen concentration. Under the highest $\mathrm{N}$ concentration $\left(10 \mathrm{mg} \mathrm{L}^{-1}\right)$ combined with the highest initial plant density (20 g per aquarium), the biomass of Ceratophyllum plants showed complete decay by the end of the experiment (Figure 2B). In Ceratophyllum-Lemna co-cultures in the range of $0.2-2 \mathrm{mg} \mathrm{N} \mathrm{L}^{-1}, \mathrm{pH}$ was quite high (9.40-10.05) and was reduced to 7.107.15 with increasing $\mathrm{N}$. DO concentration of the water showed a similar pattern to $\mathrm{pH}$ : at low $\mathrm{N}$ range $\left(0.2-2 \mathrm{mg} \mathrm{N} \mathrm{L}^{-1}\right)$ day time DO was high (11.1-14.1 $\mathrm{mg} \mathrm{L}^{-1}$ ), and at the highest $\mathrm{N}$ concentration, it was reduced to a low level (2.4$3.3 \mathrm{mg} \mathrm{L}^{-1}$ ) that was even lower in the morning (6 AM) (DO 0.1-0.3 $\mathrm{mg} \mathrm{L}^{-1}$ ).

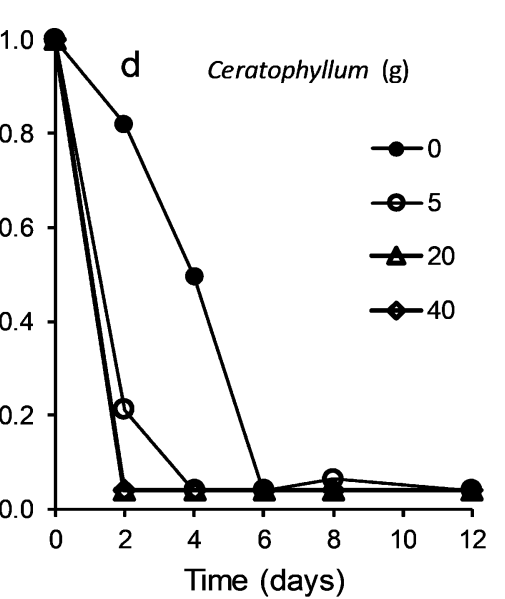

Figure 3. Change in dissolved inorganic nitrogen $\left(\mathrm{NH}_{4}{ }^{+}-\mathrm{N}\right.$ plus $\left.\mathrm{NO}_{3}{ }^{-}-\mathrm{N}\right)$ concentration of the water in LemnaCeratophyllum co-cultures grown on static medium with various initial nitrogen concentrations of $10(\mathbf{A}), 5(\mathbf{B}), 2(\mathbf{C})$ and 1 (D) $\mathrm{mg} \mathrm{L}^{-1}($ mean $n=3)$. 


\section{Static Experiment}

\section{Competition for Nutrients}

Ceratophyllum grew in all treatments, but its growth was slightly lower at $10 \mathrm{mg} \mathrm{N} \mathrm{L}^{-1}$ than at $5 \mathrm{mg} \mathrm{N} \mathrm{L}{ }^{-1}$. The growth of Lemna in the control treatment at higher nitrogen levels $\left(2-10 \mathrm{mg} \mathrm{N} \mathrm{L}^{-}\right.$ $\left.{ }^{1}\right)$ was rather high $\left(\mathrm{RGR}_{0-12} \quad 0.214-0.291 \mathrm{day}^{-1}\right)$. The biomass of Lemna showed an exponential growth for the experimental period (Figure S1). The RGR of Lemna co-cultured with Ceratophyllum showed a gradual decrease during the incubation. Depending on the initial nitrogen concentration, Ceratophyllum plants (40 g WW) lowered the growth rate during the first 8 days by $63-83 \%$ (Figure 1B). Ceratophyllum plants showed a significantly $(P=0.005, \mathrm{MD} 0.016 \pm 0.005, \mathrm{PC})$ stronger reduction in Lemna growth under high (40 g) than low ( $5 \mathrm{~g}$ ) plant density. This lower growth of Lemna was even stronger during the last 4 days of the experiment, where in most cases RGR was below $0.05 \mathrm{day}^{-1}$ in the presence of Ceratophyllum.

Total chlorophyll concentration of Lemna sensitively indicated the effects of Ceratophyllum. In the static experiment, chlorophyll concentration was significantly $(P<0.001 ; \mathrm{MD} 6.82 \pm 0.24$, $\mathrm{PC})$ lower in aquaria where Lemna was co-cultured with Ceratophyllum (Figure S2). Depending on the nitrogen concentration, Ceratophyllum plants (40 g WW) lowered the total chlorophyll concentration of Lemna by 57-75\% and Lemna plants showed significantly $(P<0.000, \quad \mathrm{MD} 2.46 \pm 0.24, \quad \mathrm{PC})$ higher drop in tissue chlorophyll concentration under high (40 g) than low (5 g) Ceratophyllum density (Figure S2). Dry matter content (DMC) of Lemna decreased with increasing $\mathrm{N}$ concentration, and on the other hand, it increased with higher Ceratophyllum density (40 g FW) (Table S1, Figure S3).

\section{Differences in Chemical Composition}

The concentration of most nutrients showed a sharp drop in the presence of Ceratophyllum during the first four days of the experiment (Figure 3). In the control treatment without Ceratophyllum, nutrient concentrations declined steadily. In the presence of Ceratophyllum already more than 95\% of $\mathrm{NH}_{4}{ }^{+}-\mathrm{N}$ was removed from the water on the second day. Depending on the initial $\mathrm{N}$ concentration and Ceratophyllum densities, $\mathrm{N}$ dropped to $0.04 \mathrm{mg} \mathrm{L}^{-1}$ after 2-6 days (Figure 3). After 4 days, concentrations of $\mathrm{P}, \mathrm{Fe}$ and $\mathrm{Mn}$ dropped to $0.02,0.01$ and $0.001 \mathrm{mg} \mathrm{L}^{-1}$, respectively (Figure 4A-C). In Ceratophyllum (5-40 g FW)-treated aquaria within 2 days, $\mathrm{pH}$ showed a sharp increase above 10.0, whereas in control aquaria it remained rather stable until 6 days (7.8-7.9) and then showed a steady rise up to 9.11 (Figure 4D). C:N molar ratio of the fronds decreased with increasing $\mathrm{N}$ concentration and was higher with increasing Ceratophyllum densities (Figure S4). With the treatment of Ceratophyllum (5-40 g FW) at $5 \mathrm{mg} \mathrm{N} \mathrm{L}{ }^{-1}, \mathrm{C}: \mathrm{N}$ ratio in Lemna fronds was increased by $228-414 \%$; on the other hand, manganese concentration was reduced by $80-88 \%$ (Figure S4). The pattern in Lemna DMC was parallel to $\mathrm{C}: \mathrm{N}$ molar ratio.

\section{Field Survey from the Database of Hungarian and Dutch Surface Waters}

Based on the Database of Hungarian Surface Waters $(n=305)$ united with the Dutch ditches survey $(n=67)$, the concentration for total nitrogen was $2.13 \mathrm{mg} \mathrm{L}^{-1} \pm 0.17 \mathrm{SE}$ in the water bodies that were dominated by Ceratophyllum (DAFOR scale 4$5, n=79)$, while it was $4.72 \mathrm{mg} \mathrm{L}^{-1} \pm 0.69 \mathrm{SE}$ for L. gibba $(n=21)$.

A GLM with a multinomial probability distribution and a cumulative logit link function showed that cover class (expressed in DAFOR scale) of $L$. gibba was significantly correlated with increasing total $\mathrm{N}$ (Wald Chi-square $=14.902, \quad$ d.f. $=1$, $P=0.000$, slope $=0.161$, Table S2), while $C$. demersum was significantly correlated with decreasing total $\mathrm{N}$ (Wald Chi-Square $=24.621$ d.f. $=1, P<0.000$, slope $=-0.191$, Table S3).

The cover of $C$. demersum was higher than of $L$. gibba below $3 \mathrm{mg} \mathrm{L}^{-1}$ total-N, whereas the cover of $L$. gibba exceeded $C$. demersum cover above $5 \mathrm{mg} \mathrm{N} \mathrm{L}^{-1}$ (Figure 5). The cover of L. gibba showed a negative correlation with the frequency of $C$ demersum, and the cover of $C$. demersum was negatively correlated with $L$. gibba frequency (Figure 6).

\section{Discussion}

Our results show that the growth of duckweed in the low and medium nitrogen range was much lower in the presence of coontail. Furthermore, duckweed was increasingly less affected by coontail at higher nitrogen concentrations which were particularly strongly visible in the semi-static experiments where growth media were renewed twice a week at 5-10 $\mathrm{mg} \mathrm{N} \mathrm{L}^{-1}$ (71-142 $\mathrm{mg} \mathrm{N} \mathrm{m}^{-}$ ${ }^{2}$ day $^{-1}$ ) and Lemna was able to overgrow the surface completely. Our experiment showed that $\mathrm{N}$ removal was rapid with a calculated $\mathrm{N}$ removal 

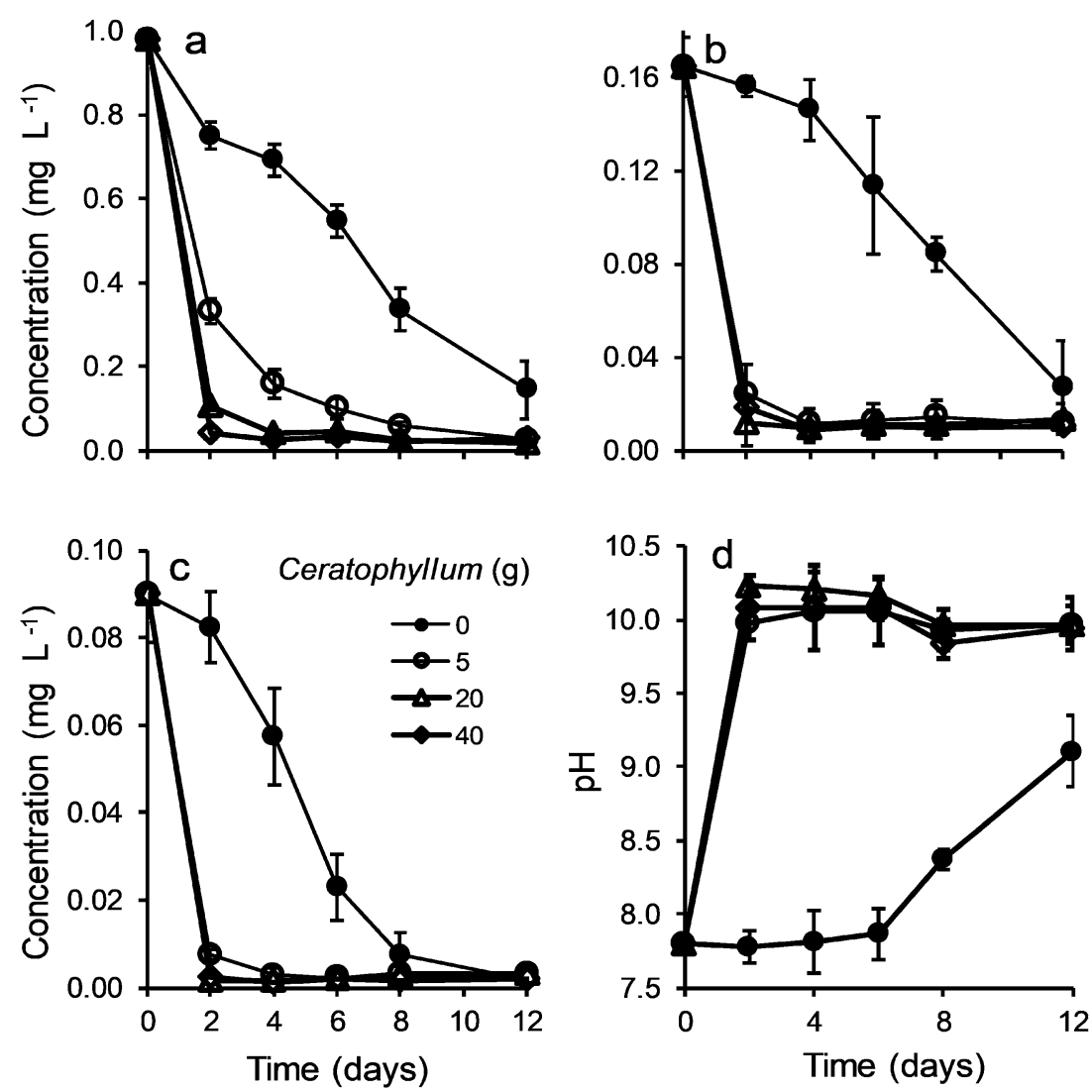

Figure 4. Chemical composition; $\mathbf{A} \mathrm{PO}_{4}{ }^{3-}-\mathrm{P}, \mathbf{B}$ total iron, $\mathbf{C}$ total manganese, $\mathbf{D}$ pH of the water in Lemna-Ceratophyllum co-cultures grown on static medium under five different initial nitrogen concentrations $\left(0.5-10 \mathrm{mg} \mathrm{N} \mathrm{L}^{-1}\right)$. For each Ceratophyllum density, the mean of all nitrogen treatments is given (mean $\pm \mathrm{SD}, n=5$ ).

capacity by Ceratophyllum of $5-9 \mathrm{mg} \mathrm{N} \mathrm{d}^{-1}$ in the range of $0.5-2 \mathrm{mg} \mathrm{N} \mathrm{L}^{-1}$. Even at high $\mathrm{N}$ concentrations $\left(5 \mathrm{mg} \mathrm{N} \mathrm{L}^{-1}\right)$, the high density of Ceratophyllum likely resulted in $\mathrm{N}$ limitation after $48 \mathrm{~h}$ in these static conditions. As a consequence, Lemna in the semi-static experiment in the range of $0.2-$ $2 \mathrm{mg} \mathrm{N} \mathrm{L}^{-1}$ per week was partially grown under $\mathrm{N}$ limited conditions (before renewal), but this limitation was less strong than in the static experiment due to the renewal of the medium. Lemna was able to completely cover the surface at higher $\mathrm{N}$ concentrations at a rate depending on the $\mathrm{N}$ concentration. High densities of duckweed cover strongly limit the amount of available light leading to very unfavourable conditions for the growth of submerged plants (Peeters and others 2013; Scheffer and others 2003). In parallel with our laboratory results, the field surveys with the occurrence of the two macrophytes also revealed that the dominance of $C$. demersum over $L$. gibba occurred at low $\left(<3 \mathrm{mg} \mathrm{N} \mathrm{L}^{-1}\right)$, whereas L. gibba dominated over C. demersum at high ( $>5 \mathrm{mg} \mathrm{N} \mathrm{L}^{-1}$ ) total nitrogen. The frequency of Lemna showed a positive corre- lation with total nitrogen in the water, while Ceratophyllum had a negative pattern. Furthermore, the occurrence of $L$. gibba negatively correlated with frequency of $C$ demersum. Therefore, both our experimental and field survey results are well in line with the view that asymmetric competition for light and nutrients allows submerged plants to dominate at lower but not at higher nutrient concentrations (van Zuidam and Peeters 2013; Smith 2014; van Gerven and others 2015) (Figure 7).

Similar to rooted submerged plants (Szabó and others 2010), the present experiments show that rootless submerged plants can change the chemical composition of the medium drastically since among the analysed nutrients, N, P and Fe were strongly reduced in the medium. Beyond plant nutrient uptake, the concentration of phosphate (Otsuki and Wetzel 1972), iron and manganese (Stumm and others 1960; Stumm and Morgan 1995) may be further reduced by the precipitation due to high $\mathrm{pH}$ and oxygen levels associated with the photosynthesis of submerged macrophyte-periphyton complex (Roijackers and others 2004; Szabó and 


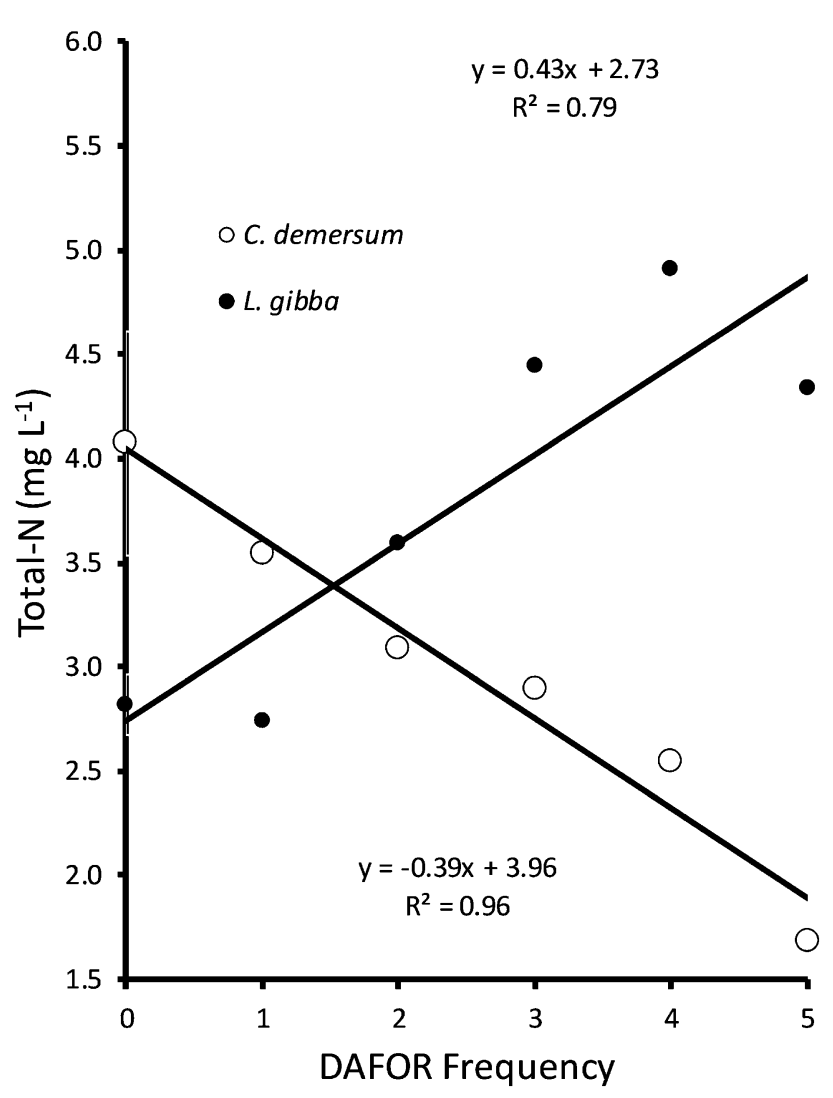

Figure 5. Correlation of the frequency of Lemna gibba and Ceratophyllum demersum with total $\mathrm{N}$ concentration (mean $\pm n \mathrm{SE}$ ). Data were collected from the database of the Hungarian surface waters $(n=290)$ and Dutch ditches $(n=68)$. Frequency data are shown in DAFOR scale.

others 2005). Because substantial concentrations of these elements ( $\mathrm{N} \mathrm{0.22,} \mathrm{P} \mathrm{0.03,} \mathrm{Fe} \mathrm{0.028,} \mathrm{mg} \mathrm{L}^{-1}$ ) are needed to maintain minimal growth of floating plants (Landolt, and Kandeler 1987; Vermaat and Hanif 1998; Cedergreen and Madsen 2002), depletion of macro- and micronutrients as occurred in both experiments, may well explain the inhibitory effects.

Our static experiment showed that the effect of different densities of Ceratophyllum did not lead to characteristic differences in growth limitation of Lemna which is probably due to the rapid onset of nutrient limitation not only at low but also at intermediate nitrogen concentrations. Here the drop in the nutrient concentration of the medium seems to correlate with the strong growth inhibition of Lemna in concert with the very low tissue chlorophyll and nitrogen concentration together with increased DMC content (Weiher and others 1999). In our semi-static experiment, this limiting effect of Ceratophyllum is less pronounced resulting in a clearer effect of Ceratophyllum density on the RGR of Lemna.

The nutrient depletion that seems to have been a key process may not be the only reason explaining the growth inhibition of floating plants. Because underwater photosynthesis is an alkalinisation process as reflected by the release of $\mathrm{OH}^{-}$ions (Pedersen and others 2013), the submerged coontail elevated the pH level $(>10)$ roughly 2 units higher than without coontail which is far beyond the range $(\mathrm{pH} 5-9)$ for optimal growth of Lemna species (McLay 1976; Landolt and Kandeler 1987). We detected that even at high nitrogen supply $\left(5 \mathrm{mg} \mathrm{N} \mathrm{L}^{-1}\right)$, the growth rate, nitrogen and chlorophyll concentration of Lemna was much lower in the presence of Ceratophyllum than in the control culture at the lowest nutrient concentration (0.5 $\mathrm{mg} \mathrm{N} \mathrm{L}^{-1}$ ). Thus, this implies that besides the nutrient limitation, pH-related growth inhibition may also have played a key role, since high $\mathrm{pH}$ $(\mathrm{pH}>9.0)$ may reduce the bioavailability of anions $\left(\mathrm{PO}_{4}{ }^{3-}\right.$ and $\mathrm{NO}_{3}{ }^{-}$) (Loeppert and others 1977; Ullrich-Eberius and others 1981). In fact, in competition experiments between free-floating plants and planktonic algae, Szabó and others $(1999,2005)$ found that the growth of Lemna was negatively correlated with elevated $\mathrm{pH}$ due to algae. Because high $\mathrm{pH}$ has frequently been found 

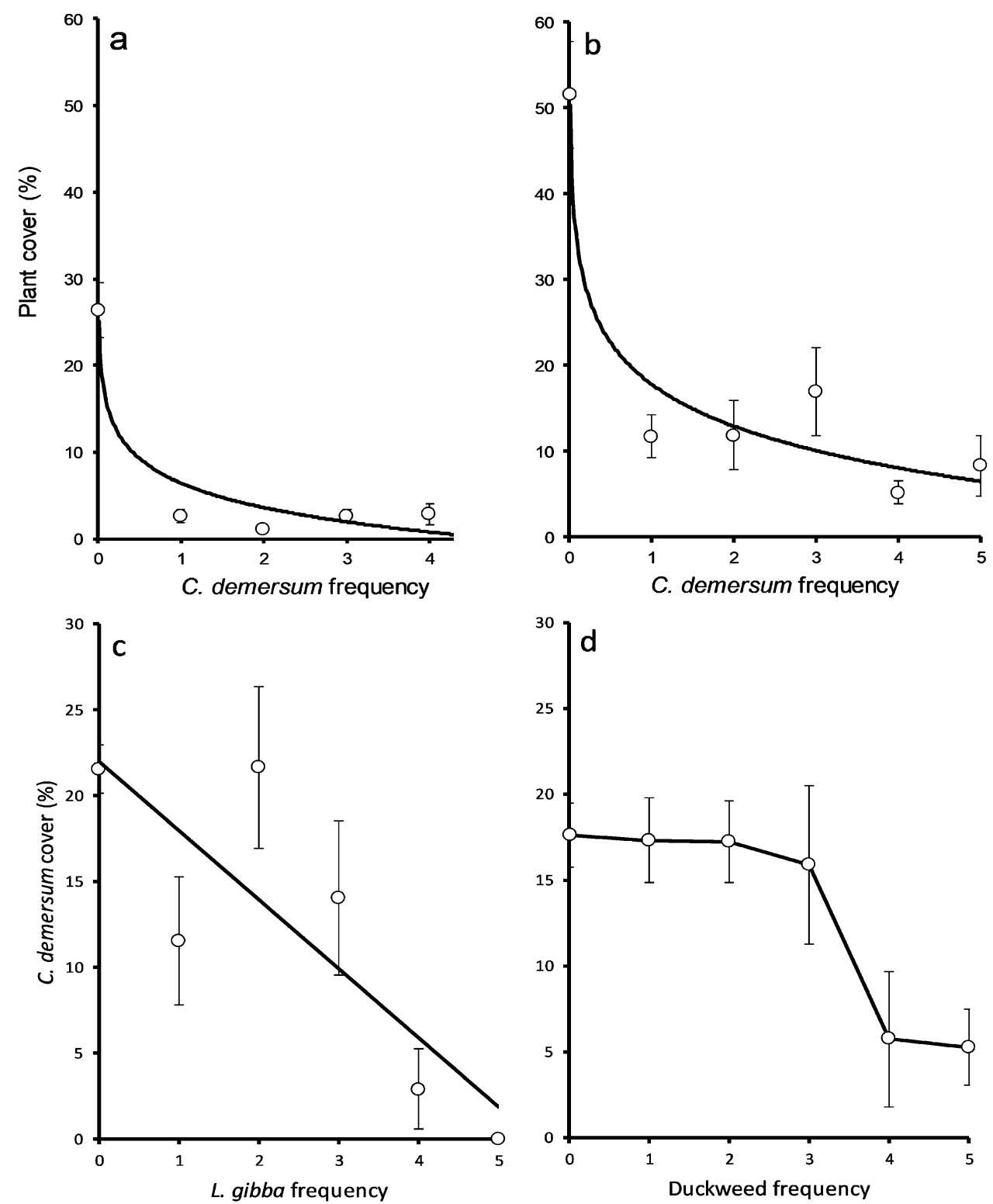

Figure 6. Correlation of the cover of Lemna gibba (A) and of free-floating duckweed species (B) with the frequency of Ceratophyllum demersum. Correlation of the cover of $C$. demersum with the frequency of Lemna gibba $(\mathbf{C})$ and free-floating duckweed species $(\mathbf{D})$ (mean $\pm n \mathrm{E}$ ). Data were collected from the database of the Hungarian surface waters $(n=301)$ and Dutch ditches $(n=72)$. Frequency data are shown in DAFOR scale.

above dense stands of submerged plants too (Spencer et al., 1994; James and others 1999; O'Sullivan and Reynolds 2004; Stiers and others 2011; Pedersen and others 2013), such an inhibitory mechanism due to high $\mathrm{pH}$ may play a role not merely in laboratory experiments, but also under field conditions. In the framework of alternative stable states, these synergistic influences due to high $\mathrm{pH}$ together with nutrient limitation will tend to intensify the negative effect of rootless submerged plants on floating plants, implying an even higher chance for hysteresis (Scheffer and others 2003; Scheffer and van Nes 2007).

Comparing our laboratory results to an earlier study (Szabó and others 2010), we may conclude that rooted submerged macrophytes (Elodea nuttallii) even at relatively low density can suppress the growth of floating plants even stronger than rootless submerged plants performed in the present study. The presence of Elodea resulted in faster exhaustion of nutrients (phosphate) combined with higher $\mathrm{pH}$ (10.30) and stronger drop in Lemna growth (lowest RGR -0.01 day $^{-1}$ ) than Cerato- 


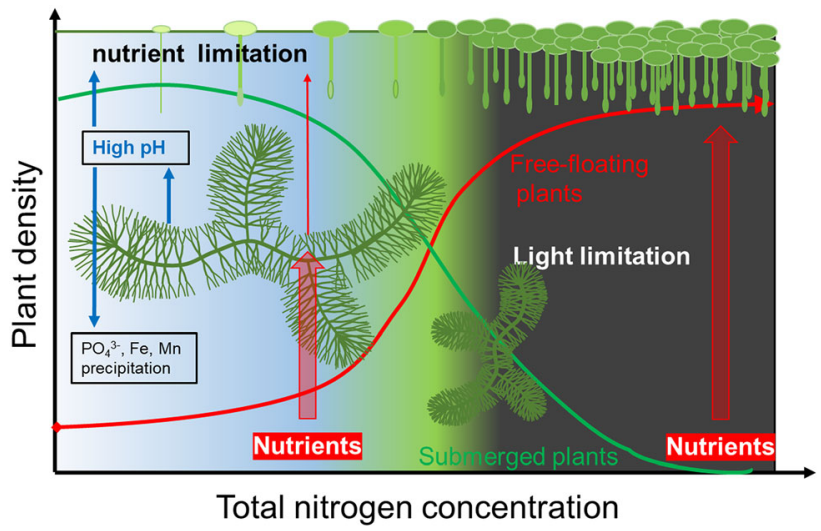

Figure 7. Mechanisms involved in maintaining the dominance of rootless submerged plants or the dominance of freefloating plants depending on the total nitrogen concentration.

phyllum performed here (Szabo and others 2010). This may indicate that the hysteresis is stronger for rooted submerged vegetation than for rootless submerged vegetation.

As several buffering mechanisms were eliminated, our laboratory experiments may overestimate the inhibitory effects of rootless submerged plants on floating macrophytes. For instance, the higher temperature that have frequently been measured above dense stands of submerged vegetation (Scheffer 1998) may have a stimulating impact on the growth of floating plants. Furthermore, continuous nutrient release from sediments and water movement could also weaken the competitive impacts of rootless submerged vegetation on floating plants. In addition, degradation compounds from plants like fulvic acids can form complexes with metals (Cerozi 2020) and may have a positive effect on floating plant growth by preventing the precipitation of Fe and $\mathrm{Mn}$. It is also well known that grazing snails (i.e. Radix labiata) consuming the periphyton on the surface of Ceratophyllum and by the release of nutrients into the water (Pinowska 2002; Yang and others 2020), could also modify the competitive outcome between the two species. In contrast to field conditions, much higher $\mathrm{pH}$ levels (10.2-10.6) were detected above dense cover of submerged rootless vegetation than in our laboratory experiment (Frodge et al. 1990; Spencer and others 1994; Pedersen and others 2013).

All in all, results from both our laboratory experiments and the field survey correspond with the theory that rootless submerged plants can sustain their dominance over floating macrophytes until nutrient loading becomes too high (Figure 7) (Scheffer and others 2003; Szabó and others 2010). With increasing nutrient concentration, the growth of floating macrophytes becomes less limited and they may gradually cover the surface. Because their shading effect lowers nutrient uptake of submerged plants (Szabó and others 2020), this then can trigger a positive feedback for floating plants. The system may then irreversibly 'jump' to a stable state of dense floating plant cover with anoxic conditions that ultimately cause the complete decay of submerged vegetation (Portielje and Roijackers 1995; van Gerven and others 2015) (Figure 7).

\section{ACKNOWLEDGEMENTS}

We like to thank the PLONS researchers Jeroen van Zuidam, Annelies Veraart and Jeroen de Klein for the use of the data. The research was supported by the European Union and the State of Hungary, cofinanced by the European Regional Development Fund in the project of GINOP-2.3.2.-15-201600009 'ICER'.

\section{Declarations}

Conflict of interest The authors declare that they have no conflict of interest.

\section{OPEN ACCESS}

This article is licensed under a Creative Commons Attribution 4.0 International License, which permits use, sharing, adaptation, distribution and reproduction in any medium or format, as long as you give appropriate credit to the original author(s) and the source, provide a link to the Creative Commons licence, and indicate if changes were made. The images or other third party material in this article are included in the article's Creative 
Commons licence, unless indicated otherwise in a credit line to the material. If material is not included in the article's Creative Commons licence and your intended use is not permitted by statutory regulation or exceeds the permitted use, you will need to obtain permission directly from the copyright holder. To view a copy of this licence, visit $h$ ttp://creativecommons.org/licenses/by/4.0/.

\section{REFERENCES}

Barko JW, Smart RM. 1985. Laboratory culture of submerged freshwater macrophytes on natural sediments. Aquat Bot 21:251-263. https://doi.org/10.1016/0304-3770(85)90053-1.

Bornette G, Puijalon S. 2011. Response of aquatic plants to abiotic factors: a review. Aquat Science 73:1-14.

Brönmark C, Vermaat JE. 1998. Complex fish-snail-epiphyton interactions and their effects on submerged freshwater macrophytes. In: Jeppesen E, Søndergaard M, Søndergaard M, Christoffersen K, Eds. The Structuring Role of Submerged Macrophytes in Lakes, . New York: Springer. pp 47-68.

Cao T, Ni L, Xie P, Xu J, Zhang M. 2011. Effects of moderate ammonium enrichment on three submerged macrophytes under contrasting light availability. Freshwater Biol 56:16201629. https://doi.org/10.1111/j.1365-2427.2011.02601.x.

Cedergreen N, Madsen TV. 2002. Nitrogen uptake by the floating macrophyte Lemna minor. New Phytol 155:285-292. https://d oi.org/10.1046/j.1469-8137.2002.00463.

Cerozi BS. 2020. Fulvic acid increases iron bioavailability in aquaponic systems: Theoretical designs and practical considerations to prevent iron deficiency in plants. Aquac Eng 90:102091. https://doi.org/10.1016/j.aquaeng.2020.102091.

Chambers PA. 1987. Light and nutrients in the control of aquatic plant community structure. I. situ observation. J Ecol 75:621628. https://doi.org/10.2307/2260194.

Chambers PA, Kalff J. 1987. Light and nutrients in the control of aquatic plant community structure. I. situ experiments. J Ecol 75:611-619. https://doi.org/10.2307/2260193.

Dai Y, Tang H, Chang J, Wu Z, Liang W. 2014. What's better, Ceratophyllum demersum L. or Myriophyllum verticillatum L., individual or combined? Ecol Eng 70:397-401. https://doi.or g/10.1016/j.ecoleng.2014.06.009.

Feuchtmayr H, Moran R, Hatton K, Connor L, Heyes T, Moss B, Harvey I, Atkinson D. 2009. Global warming and eutrophication: effects on water chemistry and autotrophic communities in experimental hypertrophic shallow lake mesocosms. J Appl Ecol 46:713-723. https://doi.org/10.1111/j.1365-2664. 2009.01644.x.

Frodge JD, Thomas GL, Pauley GB. 1990. Effects of canopy formation by floating and submergent aquatic macrophytes on the water quality of two shallow Pacific Northwest lakes. Aquat Bot 38:231-248.

James CS, Eaton JW, Hardwick K. 1999. Competition between three submerged macrophytes. Hydrobiologia 415:35-40.

Landolt E, Kandeler R. 1987. The Family of Lemnaceae-a Monographic Study. Vol. 2. Zürich: Veröffentlichungen des Geobotanischen Institutes ETH. p p95.

Larson D. 2007. Growth of three submerged plants below different densities of Nymphoides peltata (S. G. Gmel.) Kuntze. Aquat Bot 86:280-284.
Lichtentaler KH. 1987. Chlorophylls and carotenoids: pigments of photosynthetic biomembranes. Methods Enzymol 148:350382.

Loeppert H, Kronberger W, Kandeler R. 1977. Correlation between nitrate uptake and alkalinisation by Lemna paucicostata 6746. In: Thellier M, Monnier A, Demarty M, Eds. Transmembrane Ionic Exchanges in Plants, . Paris et Mount Saint Aignan: Edit CNRS et Université Rouen. pp 283-288.

Lombardo P, Cooke GD. 2003. Ceratophyllum demersum-phosphorus interactions in nutrient enriched aquaria. Hydrobiologia 497:79-90.

Lu J, Wang Z, Xing W, Liu G. 2013. Effects of substrate and shading on the growth of two submerged macrophytes. Hydrobiologia 700:157-167.

McLay CL. 1976. The effect of pH on the population growth of three species of duckweed: Spirodela oligorrhiza, Lemna minor and Wolffia arrhiza. Freshwater Biol 6:125-136.

Mjelde M, Faafeng B. 1997. Ceratophyllum demersum hampers phytoplankton development in some small Norwegian lakes over a wide range of phosphorus concentrations and geographical latitude. Freshwater Biol 37:355-365.

Morris K, Bailey PCE, Boon PI, Hughes L. 2003. Alternative stable states in the aquatic vegetation of shallow urban lakes. II. Catastrophic loss of aquatic plants consequent to nutrient enrichment. Marine Freshwater Res 54:201-215.

Morris K, Harrison KA, Bailey CPE, Boon PI. 2004. Domain shifts in the aquatic vegetation of shallow urban lakes: the relative roles of low light and anoxia in the catastrophic loss of the submerged angiosperm Vallisneria americana. Marine Freshwater Res 55:749-758.

NNI. 1990. Water-photometric determination of the content of ammonium nitrogen and the sum of the contents of ammoniacal and organically bound nitrogen according to Kjeldahl by continuous flow analysis. Nederlands Normalisatie-Insituut, Normcommissie, 390147 "Waterkwaliteit", Delft, The Netherlands.

NNI, 1997. Water-determination of nitrite nitrogen and nitrate nitrogen and the sum of both by flow analyses (CFA and FIA) and spectrometrical detection. Nederlands Normalisatie-Insituut, Normcommissie 390147 "Waterkwaliteit", Delft, The Netherlands.

O'Sullivan PE, Reynolds CS. 2004. The Lakes Handbook. Limnology and Limnetic Ecology. Vol. 1. Oxford: Blackwell Publishing. p 699.

Otsuki A, Wetzel RG. 1972. Coprecipitation of phosphates with carbonates in marl lake. Limnol Oceanogr 17:763-767.

Pedersen O, Colmer TD, Sand-Jensen K. 2013. Underwater photosynthesis of submerged plants-recent advances and methods. Front Plant Sci 4:140.

Peeters ETHM, van Zuidam JP, van Zuidam BG, van Nes EH, Kosten S, Heuts PGM, Roijackers RMM, Netten JJC, Scheffer M. 2013. Changing weather conditions and floating plants in temperate drainage ditches. J Appl Ecol 50:585-593. https://d oi.org/10.1111/1365-2664.12066.

Phillips G, Will N, Moss B. 2016. Submerged macrophyte decline in shallow lakes: What have we learnt in the last forty years? Aquat Bot 135:37-45.

Pinowska A. 2002. Effects of snail grazing and nutrient release on growth of the macrophytes Ceratophyllum demersum and Elodea canadensis and the filamentous green alga Cladophora sp. Hydrobiologia 479:83-94. 
Portielje R, Roijackers RMM. 1995. Primary succession of aquatic macrophytes in experimental ditches in relation to nutrient input. Aquat Bot 50:127-140.

Redhead JW, Sheail J, Bullock JM, Ferreruela A, Walker KJ, Pywell RF. 2014. The natural regeneration of calcareous grassland at a landscape scale: 150 years of plant community re-assembly on Salisbury Plain, UK. Appl Veg Sci 17:408-418.

Roijackers RMM, Szabó S, Scheffer M. 2004. Experimental analysis of the competition between algae and duckweed. Archiv Hydrobiol 160:401-412.

Scheffer M. 1998. Ecology of Shallow Lakes. London: Chapman and Hall. p 357p.

Scheffer M, van Nes EH. 2007. Shallow lakes theory revisited: various alternative regimes driven by climate, nutrients, depth and lake size. Hydrobiologia 584:455-466. https://doi.org/10. 1007/s10750-007-0616-7.

Scheffer M, Hosper SH, Meijer ML, Moss B, Jeppesen E. 1993. Alternative equilibria in shallow lakes. Trends Ecol Evol 8:275-279. https://doi.org/10.1016/0169-5347(93)90254-M.

Scheffer M, Szabó S, Gragnani A, Van Nes EH, Rinaldi S, Kautsky N, Norberg J, Roijackers RMM, Franken R. 2003. Floating plant dominance as a stable state. Proc Natl Acad Sci USA 100:4040-4045.

Simons J. 1994. Field ecology of freshwater macroalgae in pools and ditches, with special attention to eutrophication. Neth J Aquat Ecol 28:25-33.

Smith SDP. 2014. The roles of nitrogen and phosphorus in regulating the dominance of floating and submerged aquatic plants in field mesocosm experiment. Aquat Bot 112:1-9.

Spencer WE, Terri J, Wetzel RG. 1994. Acclimation of photosynthetic phenotype to environmental heterogeneity. Ecology 75:301-314.

Stiers I, Njambuya J, Triest L. 2011. Competitive abilities of invasive Lagarosiphon major and native Ceratophyllum demersum in monocultures and mixed cultures in relation to experimental sediment dredging. Aquat Bot 95:161-166.

Stumm W, Lee GF. 1960. The chemistry of aqueous iron. Schweiz. Z. Hydrologie 22:295. https://doi.org/10.1007/B F02503278.

Stumm W, Morgan JJ. 1995. Aquatic Chemistry: Chemical Equilibria and Rates in Natural Waters, 3rd edn. New York: Wiley. p 1040.

Szabó S, Braun M, Borics G. 1999. Elemental flux between algae and duckweeds (Lemna gibba) during competition. Archiv Hydrobio 146:355-367.

Szabó S, Roijackers RMM, Scheffer M. 2003. A simple method for analysing the effects ofalgae on the growth of Lemna and preventing the algal growth in duckweed bioassays.Archiv für Hydrobiologie 157:567-575. https://doi.org/10.1127/0003-91 36/2003/0157-0567.

Szabó S, Roijackers RMM, Scheffer M, Borics G. 2005. The strength of limiting factors for duckweed during algal competition. Archiv Hydrobiol 164:127-140.

Szabó S, Scheffer M, Roijackers RMM, Valuto B, Braun M, Nagy PT, Borics G, Zambrano L. 2010. Strong growth limitation of floating plant (Lemna gibba) by a submerged macrophyte (Elodea nuttallii) under laboratory conditions. Freshwater Biol 55:681-690.

Szabó S, Peeters ETHM, Borics G, Veres S, Nagy PT, Lukács BA. 2020. The ecophysiological response of two invasive submerged plants to light and nitrogen. Front Plant Sci 10:1747.

Tansley AG. 1946. A guide for beginners in the study of plant communities. In: Introduction to plant ecology, Vol. 260. London: George Allen and Unwin, Ltd, Museum Street.

Tóth VR. 2013. The effect of periphyton on the light environment and production of Potamogeton perfoliatus L. in the mesotrophic basin of Lake Balaton. Aquat Sci 75:523-534.

Ullrich-Eberius CI, Novacky A, Fisher E, Luettge U. 1981. Relationship between energy-dependent phosphate uptake and the electrical membrane potential in Lemna gibba Gl. Plant Physiol 67:797-801. https://doi.org/10.1104/pp.67.4.79 7.

van Zuidam JP, Peeters ETHM. 2013. Occurrence of macrophyte monocultures in drainage ditches relates to phosphorus in both sediment and water. SpringerPlus 2:564. https://doi.org/ 10.1186/2193-1801-2-564.

van Gerven LPA, de Klein JJM, Gerla DJ, Kooi BW, Kuiper JJ, Mooij WM. 2015. Competition for light and nutrients in layered communities of aquatic plants. Am Nat 186:72-83. http s://doi.org/10.1086/681620.

Vermaat JE, Hanif KM. 1998. Performance of common duckweed species (Lemnaceae) and waterfern Azolla filiculoides on different types of waste water. Water Res 32:2569-2576.

Weiher E, van der Werf A, Thompson K, Roderick M, Garnier E, Eriksson O. 1999. Challenging Theophrastus: a common core list of plant traits for functional ecology. J Veg Sci 10:609-620.

Yang L, He H, Guan B, Yu J, Yao Z, Zhen W, Yin C, Wang Q, Jeppesen E, Liu Z. 2020. Mesocosm experiment reveals a strong positive effect of snail presence on macrophyte growth, resulting from control of epiphyton and nuisance filamentous algae: implications for shallow lake management. Sci Total Environ 705:135958. https://doi.org/10.1016/j.scitotenv.201 9.135958 . 